\title{
Association of the infusion of Heteropterys aphrodisiaca and endurance training brings spermatogenetic advantages
}

\author{
Marcos L M Gomes ${ }^{1 *}$, Juliana C Monteiro ${ }^{2}$, Karine M Freitas ${ }^{3}$, Mariana M Sbervelheri ${ }^{3}$, Heidi Dolder ${ }^{3}$ \\ ${ }^{1}$ Departamento de Ciências de Saúde, CEUNES, Universidade Federal do Espírito Santo, São Mateus, ES, Brasil. \\ 2 Departamento de Ciências Agrárias e Biológicas, CEUNES, Universidade Federal do Espírito Santo, São Mateus, ES, Brasil. \\ ${ }^{3}$ Departamento de Biologia Estructural e Funcional, Instituto de Biologia, Universidade Estadual de Campinas, Campinas, SP, Brasil.
}

\begin{abstract}
The species Heteropterys aphrodisiaca is commonly used as a stimulant by popular medicine in the Cerrado, a savanna-like biome, Brazil. Recent studies have proved its protective effects on testes of animals submitted to treatment using Cyclosporine A, as well as its stimulus effect in increasing testosterone secretion. Therefore, the present study was designed to analyze whether the association of the plant infusion and endurance exercise could potentiate the stimulating effect. The animals were separated into 4 groups: two control (sedentary and trained) receiving water and two treated (sedentary and trained) receiving the plant infusion daily (104mg/day). The proportion of the seminiferous tubule compartment and interstitium was analyzed. Within the seminiferous epithelium, the number of Sertoli and germ cells were counted in order to evaluate whether the treatment would alter the spermatogenic dynamics, analyzing: the spermatogenic yield, the mitotic and meiotic indexes, the total number of germ cells and the Sertoli cell support capacity. Trained and treated animals showed increased spermatogenic yield and spermatogonia mitosis, and no significant differences in apoptotic indexes. Despite the results showing the same pattern regarding yield and mitotic index, the meiotic index was higher in the sedentary/treated group. Therefore, the $H$. aphrodisiaca infusion increased both the testosterone production and the spermatogonia mitosis, thus increasing the spermatogenic yield.
\end{abstract}

Key words: germ cells, phytotherapy, seminiferous epithelium, spermatogenesis, testosterone.

\section{INTRODUCTION}

Nowadays, there is growing scientific interest in research on plants used in folk medicine, resulting in several studies of their active components (Pitman, 1996, Srivastava et al., 2005). The use of these plants in therapy is driven by the potential production of more affordable drugs and because of the wide popular acceptance of natural products, especially in countries with lower economic resources, such as Brazil (Corrêa et al., 2000). Despite the potential richness of medicinal flora, scientific studies and journals that address this theme are still scarce. In general, Brazil has not made satisfactory use of its biodiversity and the popular knowledge for the development of herbal agents and compounds (Calixto, 2005).

The species, Heteropterys aphrodisiaca, is a shrub that belongs to the Malpighiaceae Family, found mainly in the Cerrado region, a savanna-like biome, in the states of Mato Grosso, Goiás and northern Minas Gerais (Pio Corrêa, 1984). Its roots have been used as tonic or stimulant, as well as to treat nervous system weaknesses (Pio Corrêa, 1984; Pott and Pott, 1994; Guarim Neto, 1996). On the other hand, H. aphrodisiaca is one of the most famous aphrodisiacs in the Middle-West Brazil, popularly known as nó-de-cachorro, raiz de Santo Antônio and cordão de São Francisco (Pott and Pott, 1994; Guarim Neto, 1996).

Endurance exercise elicits several physiological responses and chronic adaptations that are critical for increasing muscular strength, hypertrophy and tolerance to physical activity. Several studies correlate the effects of exercise to the production and release of LH and testosterone (Häkkinen et al., 1988; Fry et al., 1998; Nindl et al, 2001; Tremblay et al., 2004). From the perspective of an athlete, the increased hormonal levels may act by improving performance and results, since testosterone stimulates the development of muscle and strength, as well as decreasing fat tissue accumulation (Tremblay et al., 2004).

Based on previous studies, which inferred that $H$. aphrodisiaca could increase male libido and act as an aphrodisiac species (Chieregatto, 2005; Monteiro et al., 2008), the present study was designed to assess the possible stimulating effects of $H$. aphrodisiaca infusion on the seminiferous epithelium mainly by inducing germ cell division, in the testes of adult Wistar rats, maintained sedentary or trained on a treadmill.

\section{MATERIAL AND METHODS}

Herb harvesting and experimental groups

The H. aphrodisiaca samples were harvested in Nova Xavantina (Mato Grosso, Brazil) and identified by comparison to samples kept in the Herbarium of the Federal University of Mato Grosso, under the registration number 23,928.

The roots were dried at room temperature, protected from direct incidence of sunlight, and then fragmented. Infusions were made of fragments $(25 \mathrm{~g})$ put into $100 \mathrm{~mL}$ of distilled water at boiling point. The infusion remained for four hours to cool down, then was filtered and stored at $4^{\circ} \mathrm{C}$ for up to four days, as proposed by Chieregatto (2005). The rats were weighed every week and the variation was considered in order to calculate the concentration of the infusion to be prepared.

The Central Animal House (Centro Multidisciplinar para Investigação Biológica na Área da Ciência em Animais de Laboratório - CEMIB) in the State University of Campinas 
(Unicamp) provided the male Wistar rats (Rattus norvegicus albinus) (90 days old) used in this study. The animals were divided into 4 groups $(\mathrm{n}=10)$ : a control sedentary $(\mathrm{CS})$ and a control trained group (distilled water) (CT), a sedentary treated with $H$. aphrodisiaca $(104 \mathrm{mg} /$ day) (HS) and a group that was trained and treated (HT). Food (commercial diet) and water were provided ad libitum. The plant infusion was given daily by gavage $(0.5 \mathrm{~mL} /$ animal). The same procedure was repeated with the control animals, which only received distilled water. The treatment lasted eight weeks.

The animals were kept in the Animal Facility of the Department of Cell Biology and handled in accordance with the rules of the Ethics Committee of the Institute of Biology, UNICAMP. The project had been previously submitted to the same Committee (protocol number: 734-1) and its acceptance is registered under the number 1234-1.

\section{Training protocol}

The trained animals were submitted to a training protocol that consisted of running on a treadmill built specially for small animals, with 7 individual lanes and manual control of speed, five days a week for 8 weeks, based on previously set protocols (Moraska et al., 2000; Smolka et al., 2000; Demirel et al., 2001). First, all animals were subjected to an adaptation period (pretraining), until they reached the optimal degree of effort for the initial training phase (Table I).

Biological samples

Forty-eight hours after the end of the training protocol (56 days), animals were weighed and anesthesia was injected in the left hind leg with a mixture of Xylazine and Ketamine, 5 and $80 \mathrm{mg} / \mathrm{kg}$, respectively. The blood was collected by cardiac puncture of the left ventricle and centrifuged at $10000 \mathrm{rpm}$ $\left(4^{\circ} \mathrm{C}\right)$ for 5 minutes. The testosterone assay was performed by chemiluminescence.

The animals were perfused with saline solution (0.9\%) and fixed with Karnovsky's fixative (4\% paraformaldehyde and $4 \%$ glutaraldehyde in $0.1 \mathrm{~mol} / \mathrm{L}$ phosphate buffer at $\mathrm{pH} 7.2$ ) for 20 minutes each. After perfusion, the testes were removed, weighed and put into new Karnovsky's fixative, at the same concentration, where they remained for $24 \mathrm{~h}$.

After fixation, the fragments were dehydrated in ethyl alcohol for embedding in glycol methacrylate. The blocks were

TABLE I

Treadmill protocol

\begin{tabular}{lccc}
\hline Event & Week & Velocity $(\mathrm{m} / \mathrm{min})$ & Duration $(\mathrm{min})$ \\
\hline Treadmill & 1 & 10.68 & 5 \\
adaptation & 2 & 12.42 & 7.5 \\
& 3 & 14.16 & 10 \\
Training & 1 & 14.16 & 20 \\
& 2 & 19.62 & 30 \\
& 3 & 19.62 & 40 \\
& $4-8$ & 22.92 & 45 \\
\hline
\end{tabular}

cut with a manual microtome $(4 \mu \mathrm{m})$ and the sections stained with toluidine blue/ sodium borate, $1 \%$.

Testicular morphometry

The gonadosomatic index (GSI) was calculated dividing the gonadal weight (GW) by the body weight (BW): GW/BWx100. The volume of the testicular parenchyma was obtained by subtracting the tunica albuginea volume from the testis volume. According to Paula et al. (2002), as the density of the testicle is approximately $1(1.03-1.04)$, the testicular mass was considered equal to its volume.

The volumes $(\mathrm{mL})$ of the testicular parenchyma components (seminiferous tubules and interstitium) were estimated from the proportion (\%) occupied by them within the testis. A total of 15 digital images (400x), per animal, were used in order to calculate the proportion between the two compartments. The images were analyzed using the software Image Pro Plus (v. 6.0). A grid containing 200 intersections was placed on the images and the points on the tubular and interstitial compartments were counted.

The mean seminiferous tubule diameter was obtained by randomly measuring 30 tubular cross sections, as circular as possible. Since the tubular diameter remains constant in adult male rats throughout the seminiferous cycle, it was unnecessary to consider the stage of the epithelium within the cycle (França and Russell, 1998). These sections were also used to measure the seminiferous epithelium height, which was taken from the basal membrane to the tubular lumen. The epithelium height for each tubule was the average of four diametrically opposed measurements. The total length (TL) of the seminiferous tubules, per testicle, was estimated from previous knowledge of the volume occupied by these structures within the parenchyma, as well as from the mean tubular diameter: $S T V / \pi r^{2}(S T V=$ seminiferous tubule volume; $\pi r^{2}=$ tubule cross section area; $r=$ diameter $/ 2$ ).

Germ cell line counting

The estimated populations of different cell types that make up the seminiferous epithelium in Stage 1 were based on counts of the nuclei of germ cells and nucleoli of Sertoli cells (Swierstra, 1968, Curtis and Amann, 1981, Amann and Schanbacher, 1984). The following populations were quantified in 10 seminiferous tubule cross sections: type A spermatogonia (SPTGA), primary spermatocytes at pre-leptotene/leptotene (SPT Pl/L) and pachytene (SPT P), round spermatids (RSPD) and Sertoli cells (S). Cell populations were corrected numerically considering section thickness and nuclear or nucleolar diameter, the latter in the case of Sertoli cells, as done by Amann and Almquist (1962). The average nuclear diameter is the average of 30 nuclei diameters of each cell type studied, for each animal.

The following were determined from these populations: efficiency coefficients of spermatogonial mitosis (SPT Pl/L/ SPTGA), spermatogenesis yield (RSPD/SPTGA), meiotic index (RSPD/SPT P) and Sertoli cell supporting index by the total of spermatogenic cells ((SPTGA + SPTC Pl/L + SPTC P + RSPD)/S).

\section{TUNEL assay}

In order to detect apoptosis, the TUNEL technique (Terminal deoxynucleotidyl transferase dUTP nick end labeling) was 
performed on paraformaldehyde fixed sections $(5 \mu \mathrm{m})$. TUNEL assay was made according to the Calbiochem kit protocol (\#QIA33). In brief, tissue sections were deparaffined and hydrated in ethyl alcohol, incubated with proteinase $\mathrm{K} 1 \%$ (20 minutes at room temperature), washed in distilled water and incubated with 3\% hydrogen peroxide in methanol for 5 minutes, to quench endogenous peroxidase activity. Slides were then incubated with Tdt Equilibrium Buffer in distilled water in a humid chamber at room temperature for 20 minutes and subsequently with Tdt enzyme in Tdt mix for an hour $\left(37^{\circ} \mathrm{C}\right)$. Immunoreactive cells were detected by incubating the sections with a mixture of 3,3-diaminobenzidine tetrachloride (DAB), for 13 minutes in a dark humid chamber. Sections were counterstained with Harris' hematoxylin, dehydrated in ethanol, cleared in xylene and mounted. Apoptotic nuclei were stained in brown. Extra slides of the same material were used as negative and positive controls. No color reaction was observed when TdT enzyme was omitted from the procedure. Positive control slides were incubated with DNAse (1,500U/ $\mu 1)$ in tris-buffered saline (TBS) containing $\mathrm{MgCl}_{2}(10 \mathrm{mM})$ and bovine serum albumin $(1 \mathrm{mg} / \mathrm{mL})$ for 10 minutes, prior to the endogenous peroxidase blocking process (Figure 1A-C). The same TUNEL staining steps described above were taken. Four slides, one per group, were stained at each time, avoiding discrepancies when comparing results.

\section{Apoptotic index}

Two hundred and fifty round seminiferous tubule cross sections from five animals per experimental group were evaluated for the appearance of apoptotic nuclei, at 400x magnification. Counting was based on previous studies of Turner et al. (1997), Kimura et al. (2003), and Li et al. (2009). The mean number of apoptotic cells per tubule cross section was recorded, as well as the maximum number of positive cells per cross section. The proportion of apoptotic cells was also calculated considering only positive $(+)$ tubules. In order to determine apoptotic rates, the number of each type of TUNEL-positive germ cell was divided by the total number of the corresponding type of germ cell within the seminiferous sections.

\section{Statistic analysis}

Analysis of variance (one-way ANOVA) plus Duncan's test was used to compare differences between groups. Values of $\mathrm{p}<0.05$ indicate significant differences. Two-way ANOVA was used to determine whether either the $H$. aphrodisiaca infusion or training protocol influenced the patterns analyzed, and whether there was interaction between the infusion and exercise. The software Statistica (v. 8.0, Tulsa, OK, USA) was used for all statistical analysis. All values were expressed as mean \pm SEM.

\section{RESULTS}

Hormonal assay

The sedentary animals that received the plant infusion showed significant increase in total testosterone concentration (Fig. 2 ). The trained animals did not show any alterations in this parameter compared to the control sedentary animals. There was no interaction between training on a treadmill and the infusion of the plant in the final outcome of total testosterone (two-way ANOVA).
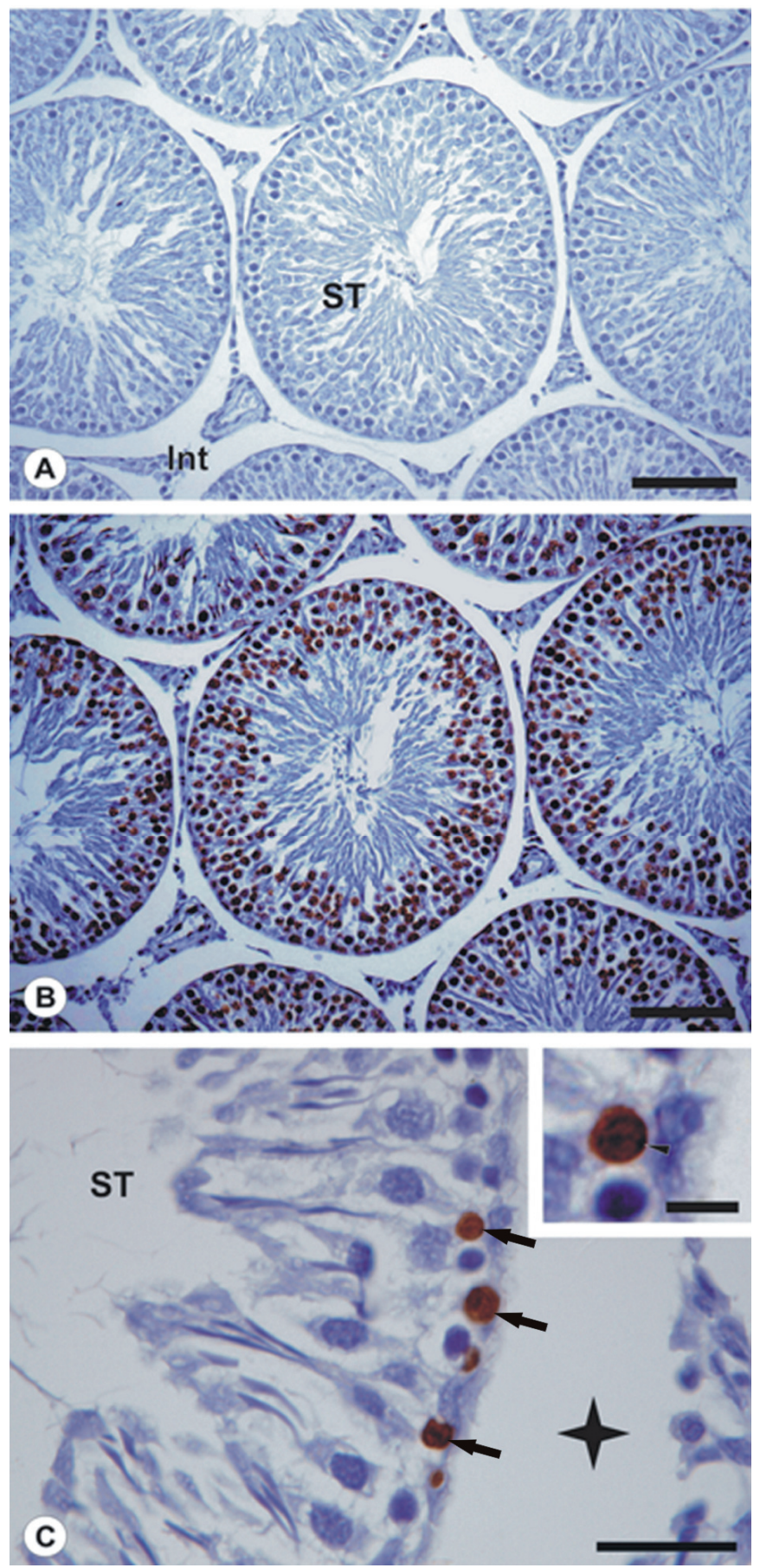

Figure 1. Histological view of the testicular parenchyma showing several seminiferous tubule cross sections in negative $(A)$ and positive (B) TUNEL controls. Brown color shows apoptotic nuclei. C: apoptotic germ cells within the seminiferous epithelium (arrows). In the inset, note the dense chromatin on the edges of a characteristically apoptotic nucleus (arrow head). ST: seminiferous tubule; Int: interstitium; star: lymphatic space. Bars: $\mathrm{A}$ and $\mathrm{B}=$ $100 \mu \mathrm{m} ; \mathrm{C}=25 \mu \mathrm{m}$; detail $=5 \mu \mathrm{m}$. 


\section{Testicular morphometry}

There were no significant alterations in the testicular and body weight throughout the study, as well as the GSI. The proportions between seminiferous tubules and interstitium remained constant among the experimental groups (Table II).

On average, both groups submitted to the exercise protocol showed significantly lower tubular diameters compared to the sedentary ones. On the other hand, the sedentary animals showed shorter seminiferous tubules, so that, despite the differences, the final volume remained constant among all treatments (Table III). The epithelium height was not significantly altered.

\section{Germ and Sertoli cells}

The number of spermatogonia decreased in animals treated and trained compared to the control trained animals (Table IV). There was also a decrease in the number of pre-leptotene and pachytene cells in animals treated with $H$. aphrodisiaca, both sedentary and trained. However, the number of round spermatids remained constant (Table IV).

The spermatogenic yield, the meiotic index and spermatogonial mitosis were calculated using the average values of the germ cell populations. Animals that received the infusion and were submitted to the exercise protocol had the highest spermatogenesis yield average and spermatogonial mitosis rate, compared with the control trained group and with both sedentary groups. The mitotic index and spermatogenesis yield showed the same tendency among the groups, however, for the meiotic index, the sedentary group receiving the infusion showed the highest average when compared to the two control groups, sedentary and trained (Fig. 3).

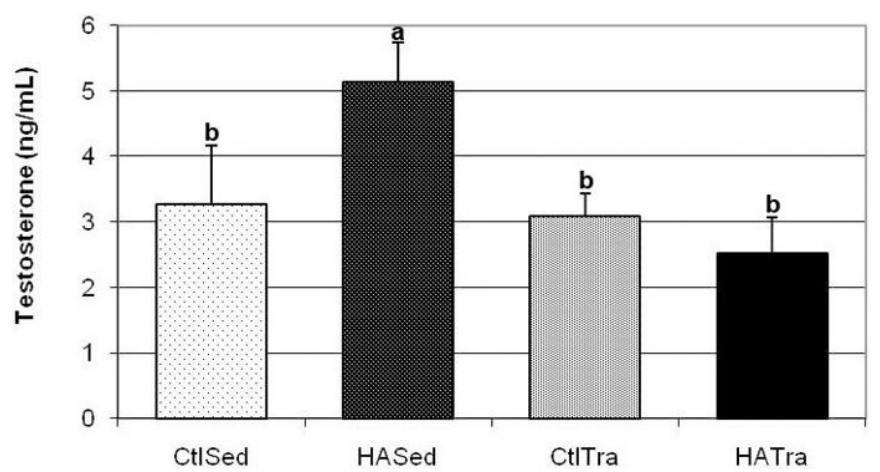

Figure 2. Testosterone concentration $(\mathrm{ng} / \mathrm{mL})$ (mean $\pm \mathrm{SD} ; \mathrm{n}=10)$. Same letters do not differ by Duncan's test $(\mathrm{p}>0.05)$.

TABLE II

Body and testicular weight, gonadosomatic index and tubules/interstitium ratio of Wistar rats treated with Heteropterys aphrodisiaca infusion and/or submitted to treadmill endurance training (mean \pm SD, for body and testicular weight and $\mathrm{GSI}$, whereas mean \pm SEM for seminiferous tubules and interstitium)

\begin{tabular}{lcccc}
\hline Parameters & CtlTra & HATra & Ct1Sed & HASed \\
\hline Body weight $(\mathrm{g})$ & $403.60 \pm 33.17^{\mathrm{a}}$ & $416.30 \pm 40.92^{\mathrm{a}}$ & $417.10 \pm 25.47^{\mathrm{a}}$ & $410.40 \pm 44.48^{\mathrm{a}}$ \\
Testicular weight $(\mathrm{g})$ & $3.37 \pm 0.14^{\mathrm{a}}$ & $3.58 \pm 0.10^{\mathrm{a}}$ & $3.43 \pm 0.08^{\mathrm{a}}$ & $3.54 \pm 0.01^{\mathrm{a}}$ \\
GSI (\%) & $0.83 \pm 0.03^{\mathrm{a}}$ & $0.86 \pm 0.04^{\mathrm{a}}$ & $0.82 \pm 0.02^{\mathrm{a}}$ & $0.86 \pm 0.02^{\mathrm{a}}$ \\
Seminiferous tubules $(\%)$ & $86.36 \pm 0.82^{\mathrm{a}}$ & $86.97 \pm 0.63^{\mathrm{a}}$ & $85.56 \pm 0.81^{\mathrm{a}}$ & $85.88 \pm 1.22^{\mathrm{a}}$ \\
Interstitium $(\%)$ & $13.64 \pm 0.82^{\mathrm{a}}$ & $13.03 \pm 0.63^{\mathrm{a}}$ & $14.44 \pm 0.81^{\mathrm{a}}$ & $14.12 \pm 1.22^{\mathrm{a}}$ \\
\hline
\end{tabular}

*Same superscripts indicate lack of statistical difference as analyzed by Duncan's test ( $\mathrm{p}>0.05 ; \mathrm{n}=10)$. Ct/Sed and Ct/Tra: Control Sedentary and Trained, respectively; HASed and HATra: Sedentary/Treated and Trained/Treated, respectively.

\section{TABLE III}

Testicular morphometry of adult Wistar rats treated with Heteropterys aphrodisiaca infusion and/or submitted to treadmill endurance training (mean \pm SEM)

\begin{tabular}{lcccc}
\hline Parameter & CtlTra & HATra & CtlSed & HASed \\
\hline Tubular diameter $(\mu \mathrm{m})$ & $316.28 \pm 4.84^{\mathrm{a}}$ & $310.56 \pm 7.46^{\mathrm{a}}$ & $295.84 \pm 3.75^{\mathrm{b}}$ & $297.28 \pm 4.74^{\mathrm{b}}$ \\
Epithelium height $(\mu \mathrm{m})$ & $107.26 \pm 1.68^{\mathrm{a}}$ & $104.31 \pm 3.01^{\mathrm{a}}$ & $100.03 \pm 1.73^{\mathrm{a}}$ & $103.38 \pm 2.60^{\mathrm{a}}$ \\
Tubular length/testis $(\mathrm{m})$ & $17.48 \pm 0.76^{\mathrm{b}}$ & $19.09 \pm 0.89^{\mathrm{ab}}$ & $20.27 \pm 0.57^{\mathrm{a}}$ & $21.25 \pm 1.08^{\mathrm{a}}$ \\
Tubular volume/ testis $(\mathrm{mL})$ & $1.37 \pm 0.06^{\mathrm{a}}$ & $1.43 \pm 0.05^{\mathrm{a}}$ & $1.39 \pm 0.04^{\mathrm{a}}$ & $1.46 \pm 0.05^{\mathrm{a}}$ \\
\hline
\end{tabular}

*Same superscripts indicate lack of statistical difference as analyzed by Duncan's test ( $>0.05 ; \mathrm{n}=10)$. Ct/Sed and Ct/Tra: Control Sedentary and Trained, respectively; HASed and HATra: Sedentary/Treated and Trained/Treated, respectively. 


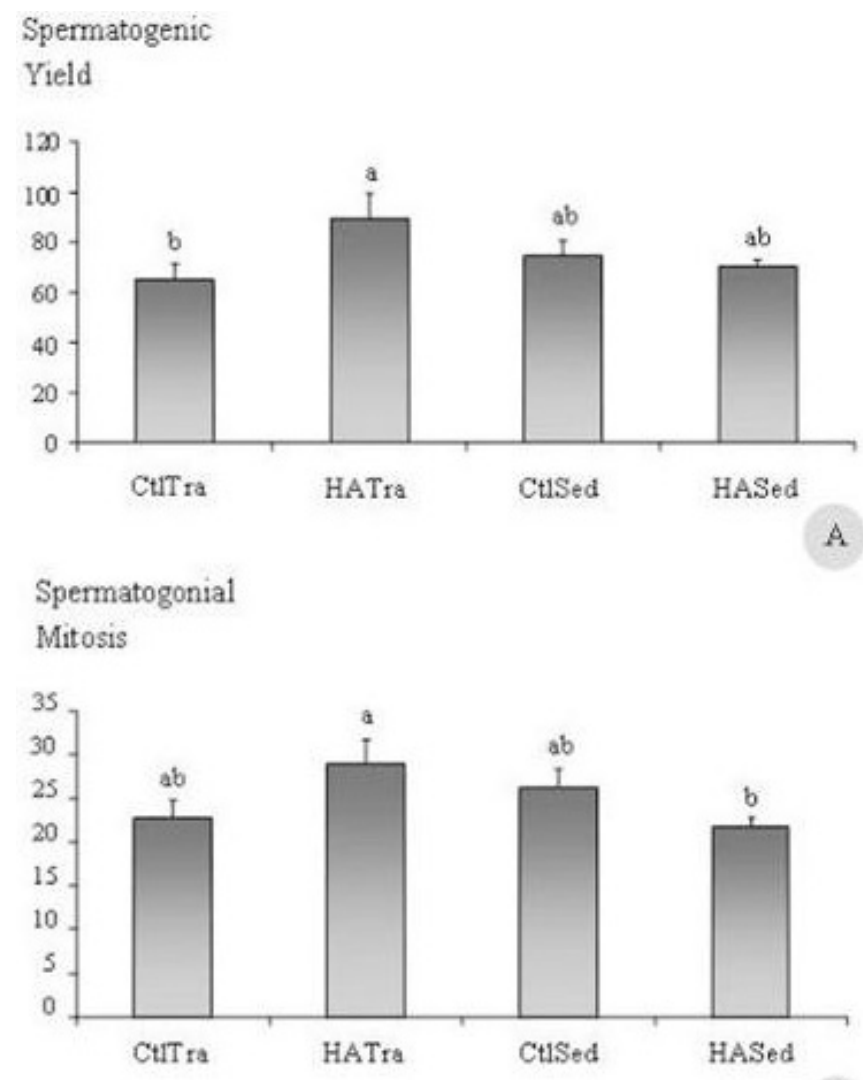

\section{Meiotic}

Index

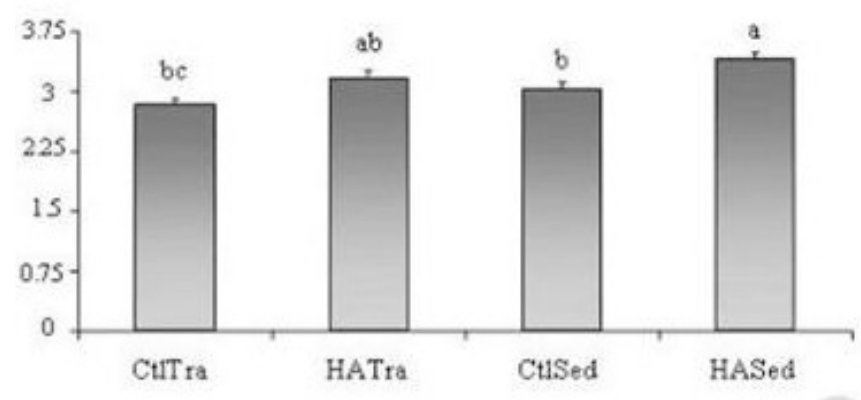

Figure 3. Spermatogenesis dynamics. A. Spermatogenic yield; B. Spermatogonial mitosis and; $C$. Meiotic index. Values are mean \pm SEM (Means with the same letters do not differ significantly; Duncan test; $\mathrm{p}>0.05, \mathrm{n}=10$ ). Ct|Tra: Control trained, HATra: Treated and trained, CtISed: Control sedentary and HASed: Treated and sedentary.

Apoptotic assay

All apoptotic results are listed on Table V. Sedentary rats that received plant treatment showed the lowest number of apoptotic cells per tubule and per positive tubule cross sections $(p<0.05)$. As well, the proportion of tubules showing at least one apoptotic germ cell was significantly lower in this group. None of the germ cells populations showed any significant alterations. Besides, apoptosis was noted mainly in spermatogonia and primary spermatocytes, and occasionally in round spermatids.

\section{DISCUSSION}

The presented data showed that both biometric data and spermatogenesis were not affected by the proposed endurance protocol. However, $H$. aphrodisiaca infusion seems to play an important role in improving testosterone secretion, as well as cell division, increasing spermatogenesis yield and the meiotic index.

Morphometry techniques have frequently been used to help in comparisons between experimental groups, thus adding more reliability to the final diagnosis. The present study was based on the principles of morphometry and stereology, in order to describe possible alterations within the testicular functions and structure of Wistar rats under exercise and/or treatment with Heteropterys aphrodisiaca infusion.

According to the protocol suggested for the present study there were no differences in the body and testicular weights after treatments, thus the gonadosomatic index did not show significant variations among groups. However, Chieregatto (2005) and Monteiro et al. (2008) working with the same animal strain and infusion dose found a greater weight gain in rats treated with $H$. aphrodisiaca infusion, which was correlated with the increased testosterone secretion in those animals. Although the sedentary, treated animals showed an increase in testosterone concentrations, there were no alterations in the weight of reproductive organs.

The seminiferous tubule compartment occupies most of the testicular parenchyma $(86 \%)$, containing somatic (Sertoli cells) and germ cell lineages (Russell and França, 1995), and thus is important during the entire spermatogenic process. Several studies have related tubular diameter and length, as well as the seminiferous epithelium height and the tubular proportion within the parenchyma to the daily sperm production. The intraperitoneal injection of alcoholic extracts of Momordica charantia (Naseem et al., 1998), and piperine (Malini et al., 1999) in rats led to a reduction of the tubular diameter, thus reducing sperm production by severe modifications of the epithelium. On the other hand, Chieregatto (2005) reported that after treating rats with Anemopaegma arvense infusion, it was possible to increase those parameters, while not increasing the total tubular volume within the parenchyma. The present study showed significant decrease of tubular diameter in sedentary rats. Seminiferous tubules are made of three basic components: tunica propria, seminiferous epithelium and lumen, where sperm is released after spermiogenesis (Ross et al., 2003). Once the epithelium height and total length did not change after treatment and/or exercise, and the tunica propria is really thin and was apparently normal in all animals, the decrease of diameter could be due to a smaller lumen.

Morphological analysis did not show any damage or major alterations due to the administration of $H$. aphrodisiaca infusion and/or the endurance exercise. The total volume occupied by the seminiferous tubules remained statistically the same among the experimental groups, despite the numerical variations of such parameters as diameter and length. Since the volume formula for the tubular compartment calculation includes both tubular diameter and length, the association of the variations observed for these parameters was related to the maintenance 
of the total volume of the seminiferous tubules. The longer the tubules, the narrower their diameters, while the shorter the tubules, the wider their diameters.

The Sertoli cell population established during the initial development of the male reproductive system determines daily sperm production in normal and sexually mature animals (Orth et al., 1988; Hess et al., 1993). This hypothesis is based on the fact that each Sertoli cell is able to support a limited number of germ cells (Russell and Peterson, 1984; França and Russell, 1998). Daily spermatogenic efficiency, which is the number of spermatozoa produced daily per gram of testis, is positively related to the number of germ cells supported by the Sertoli cell (Russell and Peterson, 1984; Sharpe, 1994; França and Russell, 1998), since the interactions between Sertoli and germ cells are crucial to maintain normal sperm production (Griswold, 1995). In the present study, the number of Sertoli cells was constant for all treatments, which was also observed for the total number of germ cells.

The number of spermatogonia and primary spermatocytes in leptotene and pachytene was significantly lower in the treated, trained animals, leading to a higher mitotic index Besides, the lower number of cells is not due to apoptosis, as was shown by the TUNEL technique. On the contrary, the number of apoptotic cells was significantly lower in the sedentary and treated animals, suggesting that the administration of the drug could act as a substance protecting the tubules by preventing apoptosis and/or seminiferous damage, as shown by Monteiro et al. (2008), who used Heteropterys aphrodisiaca infusion to protect the seminiferous epithelium against cyclosporine A administration.

Even with a lower number of primary spermatocytes in both HA treated groups, the meiotic indexes of these groups were higher than those of the controls. Meiosis seemed to occur more efficiently, producing as many round spermatocytes as in the control groups, as well as the same total number of germ cells.

Several drugs, such as Bisphenol A (Li et al., 2009), increase apoptotic cell types within either the seminiferous epithelium (spermatogonia, primary spermatocytes and spermatids) or the interstitium (Leydig cells), causing loss of germ cell

TABLE IV

Germ cells populations within seminiferous epithelium of Wistar rats treated with Heteropterys aphrodisiaca infusion and/or submitted to treadmill endurance training (mean \pm SEM)

\begin{tabular}{|c|c|c|c|c|}
\hline Number of cells $\left(\times 10^{6}\right)$ & CtlTra & HATra & CtlSed & HASed \\
\hline Sertoli/gram of testis & $11.57 \pm 0.74^{\mathrm{a}}$ & $11.15 \pm 0.71^{\mathrm{a}}$ & $13.43 \pm 0.72^{\mathrm{a}}$ & $12.66 \pm 0.76^{\mathrm{a}}$ \\
\hline Spermatogonia & $1.35 \pm 0.08^{\mathrm{a}}$ & $1.04 \pm 0.14^{\mathrm{b}}$ & $1.18 \pm 0.08^{\mathrm{ab}}$ & $1.25 \pm 0.07^{\mathrm{ab}}$ \\
\hline Spermatocytes (Pre-leptotene/Leptotene) & $29.33 \pm 0.77^{\mathrm{a}}$ & $26.68 \pm 0.97^{b}$ & $29.57 \pm 1.04^{\mathrm{a}}$ & $26.51 \pm 0.88^{b}$ \\
\hline Spermatocytes (Pachytene) & $29.48 \pm 0.58^{\mathrm{a}}$ & $25.62 \pm 0.76^{b}$ & $27.94 \pm 0.87^{\mathrm{a}}$ & $25.58 \pm 0.96^{\mathrm{b}}$ \\
\hline Round spermatids & $83.30 \pm 2.69^{a}$ & $80.64 \pm 1.70^{\mathrm{a}}$ & $84.81 \pm 3.51^{\mathrm{a}}$ & $86.39 \pm 3.40^{\mathrm{a}}$ \\
\hline Germ cells (Total) & $143.46 \pm 3.46^{\mathrm{a}}$ & $133.98 \pm 2.87^{\mathrm{a}}$ & $143.51 \pm 5.02^{\mathrm{a}}$ & $139.73 \pm 4.97^{\mathrm{a}}$ \\
\hline
\end{tabular}

*Same superscripts indicate lack of statistical difference as analyzed by Duncan's test ( $>0.05 ; n=10)$. Ct/Sed and Ct/Tra: Control Sedentary and Trained, respectively; HASed and HATra: Sedentary/Treated and Trained/Treated, respectively.

TABLE $V$

Apoptotic cells detected by TUNEL technique (mean \pm SEM)

\begin{tabular}{lcccc}
\hline Parameters/Groups & Ct1Tra & HATra & CtlSed & HASed \\
\hline Maximum/tubule & $2.50 \pm 0.45^{\mathrm{a}}$ & $3.00 \pm 1.47^{\mathrm{a}}$ & $3.00 \pm 1.05^{\mathrm{a}}$ & $0.40 \pm 0.24^{\mathrm{a}}$ \\
Mean/tubule & $0.16 \pm 0.07^{\mathrm{ab}}$ & $0.19 \pm 0.09^{\mathrm{a}}$ & $0.15 \pm 0.06^{\mathrm{ab}}$ & $0.01 \pm 0.005^{\mathrm{b}}$ \\
Mean/+tubule & $1.72 \pm 0.35^{\mathrm{a}}$ & $1.60 \pm 0.67^{\mathrm{a}}$ & $1.59 \pm 0.26^{\mathrm{a}}$ & $0.40 \pm 0.24^{\mathrm{b}}$ \\
$\%$ Tubules apoptosis & $8.50 \pm 2.87^{\mathrm{a}}$ & $8.00 \pm 3.16^{\mathrm{a}}$ & $8.40 \pm 2.32^{\mathrm{a}}$ & $0.80 \pm 0.49^{\mathrm{b}}$ \\
Cell type (\%) & & & \\
Spermatogonia & $11.08 \pm 1.18^{\mathrm{a}}$ & $12.12 \pm 7.18^{\mathrm{a}}$ & $7.27 \pm 4.54^{\mathrm{a}}$ & $2.50 \pm 2.50^{\mathrm{a}}$ \\
Primary spermatocyte & $3.22 \pm 1.18^{\mathrm{a}}$ & $1.84 \pm 0.75^{\mathrm{a}}$ & $3.31 \pm 1.91^{\mathrm{a}}$ & $0.00 \pm 0.00^{*}$ \\
Round spermatid & $0.31 \pm 0.18^{\mathrm{a}}$ & $0.14 \pm 0.14^{\mathrm{a}}$ & $0.43 \pm 0.18^{\mathrm{a}}$ & $0.00 \pm 0.00^{*}$ \\
\hline
\end{tabular}

Same superscripts indicate lack of statistical difference as analyzed by Duncan's test ( $>0.05 ; n=5)$. Ct/Sed and Ct/Tra: Control Sedentary and Trained, respectively; HASed and HATra: Sedentary/Treated and Trained/Treated, respectively.

${ }^{¥}$ Analysis carried on only on cross sections containing apoptotic cells.

*Absence of apoptotic primary spermatocyte and spermatid in the analyzed slides. 
lineages and decreased fertility rates, as well as decrease in plasma testosterone levels and testis weight, associated with morphological changes, sperm count and motility (Takao et al., 1999; Aikawa et al., 2004). Germ cell apoptosis can also be related to a combination of factors, such as alterations in hormonal parameters and testicular oxidative stress (Chaki et al., 2006).

The results observed after long term treatment with the infusion of Heteropterys aphrodisiaca showed that there were no negative changes within the seminiferous epithelium, even after a prolonged treadmill endurance protocol. Indeed, the results showed a significantly lower number/proportion of apoptosis in the testis of the treated, sedentary animals. The protective potential of this species was shown previously by Mattei et al. (2001) and Monteiro et al. (2008), who demonstrated the increasing of antioxidant species in the brain of old rats or protection of the seminiferous epithelium after exposition to Ciclosporine A, respectively. Corroborating the above cited results, the testosterone concentration in the plasma of the same experimental group was significantly higher, also showing that the Leydig cells were preserved and not affected by the treatment.

Therefore, according to the presented data, Heteropterys aphrodisiaca infusion seems to play an important role in increasing testosterone secretion and spermatogonial behavior, inducing mitosis and increasing spermatogenic yield.

\section{ACKNOWLEDGMENTS}

The authors wish to thank the Fundação de Amparo a Pesquisa do Estado de São Paulo (FAPESP) and the Coordenação de Aperfeiçoamento de Pessoal de Nível Superior (CAPES/ PROEX) for financial support.

\section{REFERENCES}

AIKAWA H, KOYAMA S, MATSUDA M, NAKAHASHI K, AKAZOME Y, MORI T (2004) Relief effect of vitamin A on the decreased motility of sperm and the increased incidence of malformed sperm in mice exposed neonatally to bisphenol A. Cell Tissue Res. 315: 119-124.

AMANN RP, ALMQUIST JO (1962) Reproductive capacity of dairy bulls. VIII. Direct and indirect measurement of testicular sperm production. J Dairy Sci 45:774-781.

AMANN RP, SCHANBACHER BD (1984) Physiology of male reproduction. J Anim Sci 57:380-403.

CALIXTO JB (2005) Twenty-five years of research on medicinal plants in Latin America: a personal view. J Ethnopharmacol 100:131-134.

CHAKI SP, MISRO MM, GAUTAM DK, KAUSHIK M, GHOSH D, CHAINY GB (2006) Estradiol treatment induces testicular oxidative stress and germ cell apoptosis in rats. Apoptosis 11:1427-1437.

CHIEREGATTO LC (2005) Efeito do tratamento crônico com extratos de Heteropterys aphrodisiaca O. Mach. e Anemopaegma arvense (Vell) Stellf. no testículo de ratos Wistar adultos. Viçosa: UFV. pp:67.

PIOCORRÊA AD, BATISTA RS, QUINTAS LEM (2000) Plantas medicinais. Do cultivo à Terapêutica. Petrópolis: Editora Vozes. pp:247.

CURTIS SK, AMANN RP (1981) Testicular development and establishment of spermatogenesis in holstein bulls. J Anim Sci 53:1645-1657.

DEMIREL HA, POWERS SK, NAITO H, HUGHES M, COOMBES JS (2001) Exercise-induced alterations in skeletal muscle myosin heavy chain phenotype: dose-response relationship. J Appl Physiol 86:1002-1008.

FRANÇA LR, RUSSELL LD (1998) The testis of domestic animals. In: MARTINEZ F, REGADERA J (eds) Male Reproduction. A Multidisciplinary Overview. 1st ed. Madrid: Churchill Livingstone. pp:197-219.

FRY AC, KRAEMER WJ, RAMSEY LT (1998) Pituitary-adrenal-gonadal responses to high intensity resistance exercise overtraining. J Appl Physiol 85:2352-2359.

GRISWOLD MD (1995) Interaction between germ cells and Sertoli cells in the testis. Biol Reprod 52:211-216.
GUARIM NETO G (1996) Plantas medicinais do Estado do Mato Grosso. Brasília: Instituto de Biociências (ABEAS). pp:72.

HÄKKINEN K, PAKARINEN A, ALÉN M, KAUHANEN H, KOMI PV (1988) Neuromuscular and hormonal adaptations in athletes to strength training in two years. J Appl Physiol 65:2406-2412.

HESS RA, COOKE PS, BUNICK D, KIRBY JD (1993) Adult testicular enlargement induced by neonatal hypothyroidism is accompanied by increased Sertoli cell and germ cell number. Endocrinology 132:26072613.

KIMURA M, ITOH N, TAKAGI S, SASAO T, TAKAHASHI A, MASUMORI $\mathrm{N}$, TSUKAMOTO T (2003) Balance of Apoptosis and Proliferation of Germ Cells

Related to Spermatogenesis in Aged Men. J Androl 242: 185-190

LI YJ, SONG TB, CAI YY, ZHOU JS, SONG X, ZHAO X, WU XL (2009) Bisphenol A Exposure Induces Apoptosis and Upregulation of Fas/FasL and Caspase-3 Expression in the Testes of Mice Toxicol Sci 108: 427-436.

MALINI T, MANIMARAN RR, ARUNAKARAN J, ARULDHAS MM, GOVINDARAJULU P (1999) Effects of piperine on testis of albino rats. J Ethnopharmacol 64:219-225.

MATTEI R, BARROS MP, GALVÃO SMP, BECHARA EJH, CARLINI ELA (2001). Heteropteris aphrodisiaca O. Machado: effects of extract BST 0298 on the oxidative stress of young and old rat brains. Phytoth Res 15: 604-607.

MONTEIRO JC, PREDES FS, MATTA SLP, HEIDI DOLDER (2008) Heteropterys aphrodisiaca Infusion Reduces the Collateral Effects of Cyclosporine A on the Testis. Anat Record 291:809-817.

MORASKA A, TERRENCE D, ROBERT LS, DAVID R, MONIKA F (2000) Treadmill running produces both positive and negative physiological adaptations in Sprague-Dawley rats. Am J Physiol Reg I 279:1321-1329.

NASEEM MZ, PATIL SR, PATIL SR, PATIL RS (1998) Antispermatogenic and androgenic activities of Momordica charantia (Karela) in albino rats J Ethnopharmacol 61:9-16.

NINDL BC, KRAEMER WJ, DEAVER DR, PETERS L, MARX JO, HECKMAN T, LOOMIS GA (2001) LH secretion and testosterone concentrations are blunted after resistance exercise in men. J Appl Physiol 91:1251-1258.

ORTH JM, GUNSALUS GL, LAMPERT AA (1988) Evidence from Sertoli cell-depleted rats indicates that spermatid number in adults depends on numbers of Sertoli cells produced during perinatal development. Endocrinology 122:787-794.

PAULA TAR, COSTA DS, MATTA SLP (2002) Avaliação histológica do testículo de capivaras (Hydrochoerus hydrochaeris) adultas. Biosci J 18:121-136.

PIOCORRÊA, M. (1984) Dicionário de Plantas Úteis do Brasil e das Exóticas Cultivadas. Rio de Janeiro: Ministério da Agricultura/Instituto Brasileiro de Desenvolvimento Florestal. pp: 293.

PITMAN V (1996) Fitoterapia. As plantas medicinais e a saúde. Lisboa: Estampa. pp: 188

POTT A, POTT VJ (1994) Plantas do Pantanal. Corumbá: Embrapa-SPI. pp: 320.

ROSS MH, KAYE GI, PAWLINA W (2003) Histology: A text and atlas. 4th ed. LWW. pp. 682-724.

RUSSELL LD, FRANÇA LR (1995) Building a testis. Tissue Cell 27:129-147

RUSSELL LD, PETERSON RN (1984) Determination of the elongate spermatidSertoli cell ratio in various mammals. J Reprod Fertil 70:635-664.

SHARPE RM (1994) Regulation of spermatogenesis. In: KNOBIL E, NEILL JD (eds) The Physiology of Reproduction. 2nd ed. New York: Raven Press. pp.1363-1434.

SMOLKA MB, ZOPPI CC, ALVES AA, SILVEIRA LR, MARANGONI S, PEREIRADASILVA L, NOVELLO JC, MACEDO DV (2000) HSP72 as a complementary protection against oxidative stress induced by exercise in the soleus muscle of rats. Am J Physiol Reg I 279:1539-1545.

SRIVASTAVA SR, KESARWANI S, KESHRI G, SINGH MM (2005) Evaluation of contraceptive activity of a mineral-herbal preparation in SpragueDawley rats. Contraception 72:454-458.

SWIESTRA, E. E. (1968) A comparison of spermatozoa production and spermatozoa output of Yorkshire and Lacombe boars. J Reprod Fertil 17:459-469

TAKAO T, NANAMIYA W, NAGANO I, ASABA K, KAWABATA K, HASHIMOTO K (1999) Exposure with the environmental estrogen bisphenol A disrupts the male reproductive tract in young mice. Life Sci. 65: 2351-2357.

TREMBLAY MS, COPELAND JL, HELDER WV (2004) Effect of training status and exercise mode on endogenous steroid hormones in men. J Appl Physiol 96:531-539.

TURNER TT, TUNG KSK, TOMOMASA H, WILSON LW (1997) Acute Testicular Ischemia Results in Germ Cell-Specific Apoptosis in the Rat. Biol Reprod 57:1267-1274 
